\title{
Peningkatan Pengetahuan Pendidikan Lingkungan dan Konservasi Siswa/Siswi SDN Tumbang Nusa 2 di Desa Taruna Jaya
}

\author{
Increasing Knowledge of Environmental Education and Conservation of Students at SDN \\ Tumbang Nusa 2 in Taruna Jaya Village
}

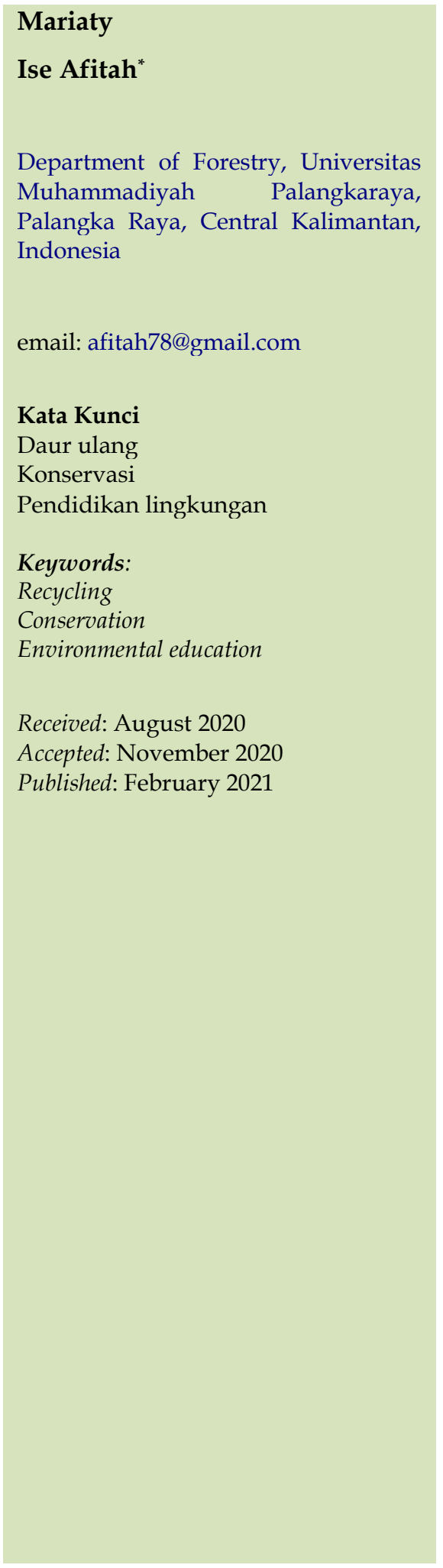

\begin{abstract}
Abstrak
Hubungan antara anak dengan alam sekitarnya merupakan landasan penting untuk membangun hubungan baik antara manusia dengan alam. Kegiatan Pengabdian masyarakat di SDN Tumbang Nusa 2 yang terletak di Desa Taruna Jaya Kecamatan Jabiren Raya Kabupaten Pulang Pisau Provinsi Kalimantan Tengah dilaksanakan pada bulan Juli sampai dengan Agustus 2019. Kegiatan yang dilaksanakan meliputi penyuluhan mengenai pendidikan lingkungan dan pemutaran Film. Memberikan pendidikan kepada anak-anak usia sekolah di dalam mengenal lingkungan dan mengelola lingkungan hidupnya, dan meningkatkan kreativitas anak-anak didalam upaya pelestarian lingkungan dan konservasi hutan. Penerapan kegiatan adalah dengan introduksi beberapa jenis tanaman yang berfungsi sebagai tanaman pelindung dan praktek menanam pohon yang baik serta memberikan pelatihan membuat barang-barang dari bahan bekas. Metode yang digunakan adalah penyuluhan, demonstrasi dan pendampingan. Mitra dalam hal ini adalah anak-anak sekolah akan memiliki pemahaman mengenai pendidikan lingkungan dan konservasi, dimulai dari pengertian lingkungan, penyebab kerusakan lingkungan, cara mengelola lingkungan hidup disekitar sekolah, serta cara mengantisipasi kerusakan lingkungan. Selain itu, mitra juga diberikan pengetahuan mengenai cara menanam dan merawat pohon dengan benar di lingkungan sekolah, keterampilan membuat prakarya dari barang-barang bekas, seperti membuat bunga dan daun dari kantong kresek plastik, membuat pot bunga dari botol plastik minuman bekas dan membuat sepeda dari kardus bekas.
\end{abstract}

\begin{abstract}
This program's main objective is to instill character education in loving the environment in children, improve thinking skills, and increase children's creativity. The relationship between children and their surroundings is an important foundation for building a good relationship between humans and nature. Community service activities at SDN Tumbang Nusa 2, located in Taruna Jaya Village, Jabiren Raya, Pulang Pisau, Central Kalimantan, were held from July to August 2019. Activities carried out included counseling on environmental education and film screenings. It provides education to school-age children in knowing the environment, managing the environment, and increasing children's creativity in environmental conservation and forest conservation efforts. The implementation of the activity is the introduction of several types of plants that function as cover crops and good tree planting practices and provide training in making goods from used materials. The methods used are counseling, demonstrations, and mentoring. In this case, partners are school children who will have an understanding of environmental education and conservation, starting from the understanding of the environment, the causes of environmental damage, how to manage the environment around schools, and how to anticipate environmental damage. Besides, partners were also given knowledge of planting and caring for trees properly in the school environment. Partners were also given skills to make crafts from used goods, such as making flowers and leaves from plastic bags, making flower pots from used plastic drink bottles, and make a bicycle from cardboard.
\end{abstract}




\section{PENDAHULUAN}

Dewasa ini kerusakan lingkungan menjadi hal yang sangat serius, dimana banyak pihak dari berbagai kalangan yang menggaungkan upaya pelestarian bagi lingkungan hidup untuk mencegah kerusakan lebih lanjut. Pasalnya saat ini telah terjadi berbagai kerusakan yang juga memberikan dampak negatif bagi kelangsungan mahluk hidupnya (Rusidyanto, 2015). Lingkungan adalah kombinasi antara unsur biotik dengan abiotik yang terdapat pada tempat yang sama. Beberapa gambar lingkungan alam telah menunjukkan terjadi perusakan hutan secara luas oleh manusia. Jika diamati secara jeli, maka sekarang Kita tengah menghadapi beragam permasalahan lingkungan (Effendi et al., 2018), diantaranya sebagai berikut:

1. Pemanasan global merupakan salah satu bentuk fenomena alam yang sedang melanda bumi. Fenomena ini terjadi karena meningkatnya aktivitas manusia yang menghasilkan gas-gas buangan. Gasgas tersebut berakumulasi dan menyebabkan terjadinya kerusakan pada lapisan atmosfer bumi, sehingga terjadi peningkatan suhu bumi.

2. Terjadinya banjir, perubahan fungsi hutan menjadi lahan perkebunan, telah berimbas pada hilang kawasan penyerap air. Sehingga ketika hujan deras datang, maka tidak ada lagi tempat untuk menampung luapan air hujan tersebut di alam. Pada akhirnya air meluap hingga ke pemukiman penduduk dan menyebabkan banjir.

3. Kebakaran hutan, kebakaran yang secara rutin berlangsung setiap tahun di kawasan Eks-PLG telah memberikan kerugian besar baik bagi masyarakat disekitar Eks-PLG maupun di luar kawasan EksPLG, bahkan ikut mempengaruhi iklim global. Dalam kaitannya dengan iklim global, diperkirakan kawasan PLG telah memberikan sumbangan emisi karbon dunia sekitar 1-8\%. Oleh karenanya tanpa strategi penyelesaian masalah peran dan fungsi kanal di PLG, maka gambut di kawasan PLG akan terus menerus terancam kehilangan jutaan karbon pada setiap terjadi kebakaran gambut. Pengelolaan saluran-saluran yang telah dibuat harus dikaitkan dengan pengelolaan wilayah sungai sebagai bagian dari ekosistem, potensi ekonomi, dan elemen pembangunan yang berkelanjutan secara adil dan merata, terpadu, holistik, dan berwawasan lingkungan.

4. Penumpukan sampah, tiap harinya masyarakat Indonesia memproduksi sampah dengan jumlah yang tidak sedikit dan dibuang begitu saja tanpa ada upaya daur ulang. Sehingga hal ini membuat keadaan lingkungan semakin memburuk tiap harinya. Sebab sampah-sampah tersebut tidak dapat terurai secara maksimal oleh alam.

Dari berbagai contoh kerusakan yang terjadi saat ini, maka perlu menggalakkan upaya pelestarian lingkungan, seperti penanaman pohon secara masal, pengelolaan sampah melalui 3R, dan sosialisasi kebijakan pemanfaatan hutan. Pendekatan pengelolaan sampah seyogyanya dilakukan melalui pendekatan berbasis $3 R$ dan berbasis masyarakat, pengelolaan sampah secara terpadu dengan melaksanakan pengelolaan sejak dari sumbernya. 3R adalah upaya yang meliputi kegiatan mengurangi (reduce), menggunakan kembali (reuse) dan mendaur ulang sampah (recycle) (Subekti et al., 2020).

Pengelolaan kawasan eks-PLG pada dasarnya adalah pengelolaan kawasan yang rusak karena dalam pembukaannya sedikit sekali memperhatikan kaidahkaidah konservasi. Karena itu, konservasi adalah pendekatan penting dalam pengelolaan kawasan eksPLG, baik sebagai kawasan lindung ataupun kawasan konservasi. Pada prinsipnya aspek konservasi bertujuan untuk menjaga fungsi hutan gambut dengan kedalaman 
$>3$ meter dalam menjaga tata air dan mempertahankan keseimbangan ekologi ekosistem hutan alam gambut baik flora dan fauna yang khas pada lahan gambut. Selain itu ekosistem gambut juga merupakan cadangan karbon yang sangat tinggi (carbon sink) (Suradiakarta, 2008).

Sumberdaya alam dapat dikelola secara lestari dan berkelanjutan jika masyarakat paham dan memiliki pengetahuan tentang pentingnya pelestarian dan pengelolaan lingkungan secara berkelanjutan. Sebagai sebuah upaya untuk mengubah cara pandang dan perilaku segenap komponen masyarakat agar memiliki kepedulian dan kesadaran yang lebih baik tentang pentingnya kelestarian lingkungan (Raunsay \& Koireowa, 2019).

Pendidikan lingkungan dan konservasi merupakan salah satu faktor penting untuk mengurangi kerusakan lingkungan hidup dan merupakan sarana yang penting dalam menghasilkan sumberdaya manusia yang dapat melaksanakan prinsip pembangunan yang berkelanjutan. Pendidikan lingkungan dilakukan sebagai upaya untuk meningkatkan pemahaman dan kepedulian masyarakat dalam mencari pemecahan dan pencegahan timbulnya masalah yang disebabkan oleh kerusakan lingkungan yang dampaknya sudah bisa kita rasakan bersama, seperti berbagai bencana alam yang akhir-akhir ini sering terjadi baik di belahan bumi maupun Indonesia. Kegiatan pendidikan lingkungan memerlukan metode atau pendekatan yang tepat sesuai dengan karakteristik persoalan dan kelompok sasaran yang dihadapi (Rivai \& Anugrah, 2011).

Tujuan utama dari program ini adalah untuk menanamkan pendidikan karakter cinta lingkungan pada anak-anak. Penanaman kembali karakter cinta lingkungan dan pemahaman akan pentingnya konservasi perlu dilakukan melalui pendidikan kepada generasi muda (anak-anak). Hubungan antara anak dengan alam sekitarnya merupakan landasan yang penting untuk membangun hubungan yang baik antara manusia dengan alam. Secara alami, anak adalah penjelajah alami. Mereka mengobservasi dan meneliti lingkungan di sekitar mereka secara alami dan belajar darinya (learning by doing) (Sari, 2014).

Pendidikan lingkungan dan konservasi merupakan salah satu faktor penting untuk mengurangi kerusakan lingkungan hidup dan merupakan sarana yang penting dalam menghasilkan sumberdaya manusia yang dapat melaksanakan prinsip pembangunan yang berkelanjutan. Pendidikan lingkungan dilakukan sebagai upaya untuk meningkatkan pemahaman dan kepedulian masyarakat dalam mencari pemecahan dan pencegahan timbulnya masalah yang disebabkan oleh kerusakan lingkungan yang dampaknya sudah bisa kita rasakan bersama, seperti berbagai bencana alam yang akhir-akhir ini sering terjadi di Indonesia. Kegiatan pendidikan lingkungan memerlukan metode atau pendekatan yang tepat sesuai dengan karakteristik persoalan dan kelompok sasaran yang dihadapi (Singkawijaya et al., 2019).

Pendidikan lingkungan tidak akan merubah situasi dan kondisi lingkungan yang rusak menjadi baik, akan tetapi memberikan pelatihan lingkungan kepada masyarakat usia sekolah akan menghasilkan masyarakat yang sadar akan betapa pentingnya keadaan lingkungan yang seimbang untuk kehidupan yang sempurna. Namun pendidikan lingkungan tidak dapat dilakukan dalam waktu yang singkat, melainkan membutuhkan proses untuk menciptakan sumber daya manusia yang peduli akan lingkungan. Atas dasar itulah Pendidikan lingkungan harus diberikan sedini mungkin, agar dapat mengurangi kerusakan lingkungan. Sebagai contohnya adalah bencana kebakaran hutan dan pembukaan lahan dengan cara membakar yang selalu terjadi dari tahun ke tahun, hal ini disebabkan karena kurangnya kesadaran 
masyarakat sekitar kawasan hutan untuk menjaga lingkungan dalam hal pembukaan lahan. Dengan adanya pendidikan lingkungan merupakan upaya memperkenalkan siswa sekolah pada lingkungan sebenarnya yang sudah ada dalam program $5 \mathrm{~K}$, Keindahan, Kerapian, Kebersihan, Kepribadian dan Keamanan (Dahnial, 2020).

Untuk membangun kadar pemahaman yang seimbang tentang peran aktif manusia ditengah pelestarian lingkungan hidup, dapat berkembang secara optimal, khususnya terkait dengan cara sajian pelajaran dan suasana pembelajaran (Budiwan, 2018). Disinilah pentingnya pendidikan lingkungan dapat diterapkan untuk menyelesaikan permasalahan-permasalahan yang terjadi di lingkungan.

Kontribusi bagi Mitra dari kegiatan Pengabdian Masyarakat ini diantaranya memberikan bekal dasar pada anak-anak usia dini berupa praktek menanam pohon yang baik dan bekal mengolah sampah yang ada disekitar menjadi barang yang bernilai guna.

Solusi yang ditawarkan untuk mengatasi permasalahan ini dengan memberikan Penyuluhan atau sosialisasi kepada anak-anak tentang hutan dan lingkungan, materi yang disampaikan disesuaikan dengan usia sehingga diharapkan mudah dicerna seperti pemutaran film sambil diskusi lepas (tidak kaku) sehingga tepat sasaran. Dalam diskusi juga di jelaskan mengenai bahaya atau dampak kebakaran bukan hanya bagi lingkungan tapi juga bagi kesehatan, sehingga mengingatkan anak-anak untuk selalu memakai masker pada musim asap, banyak meminum air putih serta mengurangi aktivitas di luar rumah akan sedikit membantu untuk menghindari akibat buruk dari kabut asap yang dihasilkan dari kebakaran hutan di sekitar desa mereka.

Menindaklanjuti Pengabdian Masyarakat sebelumnya di Desa Tumbang Nusa tentang pendidikan lingkungan berkarakter, dimana kegiatan tersebut berdampak positif pada perkembangan pengetahuan anak-anak untuk sadar terhadap lingkungan sekitarnya, dipandang perlu untuk melakukan penyuluhan yang serupa pada masyarakat di Desa Taruna Jaya. Berikutnya kegiatan dilanjutkan dengan Pelatihan Penanaman Pohon dan Pelatihan Krativitas Anak dari barang bekas. Pelatihan ini bertujuan untuk memperluas wawasan anak-anak di SDN Tumbang Nusa 2 untuk mengenal cara-cara menanam pohon yang baik dan meningkatkan kreativitas anak-anak membuat karya dari barang bekas. Melalui pelatihan ini, diharapkan anak-anak dapat menerapkan keterampilan yang di dapat pada kehidupan sehari-hari.

Lokasi yang digunakan untuk Pelatihan ini Kegiatan Pengabdian masyarakat dilaksanakan diSDN Tumbang Nusa 2 yang terletak di Desa Taruna Jaya Kecamatan Jabiren Raya Kabupaten Pulang Pisau Provinsi Kalimantan Tengah pada bulan Juli - Agustus 2019 bertempat di salah satu ruangan kelas di sekolah dasar tersebut. Lokasi kegiatan berada pada lahan gambut yang mudah terbakar sehingga diharapkan dengan adanya kegiatan ini terbentuk adanya kesadaran masyarakat usia dini untuk merawat, menjaga, melindungi dan menghargai sumber daya alam terutama hutan rawa gambut yang cenderung selalu terbakar sepanjang tahun di desa Taruna Jaya.

\section{METODOLOGI}

Metode yang digunakan dalam pengabdian kepada masyarakat dengan tema "Peningkatan Pengetahuan Pendidikan Lingkungan dan Konservasi Siswa/Siswi SDN Tumbang Nusa 2 Di Desa Taruna Jaya" adalah berupa Penyuluhan tentang Pendidikan Lingkungan, Peragaan Penanaman Pohon dan Pelatihan Kreativitas Anak dari barang bekas. Kegiatan Pengabdian masyarakat dilaksanakan di SDN Tumbang Nusa 2 yang terletak di Desa Taruna Jaya Kecamatan Jabiren 
Raya Kabupaten Pulang Pisau Provinsi Kalimantan

Tengah (Gambar 1) pada bulan Juli - Agustus 2019 bertempat di salah satu ruangan kelas di sekolah dasar tersebut. Pelaksanaan ini dilaksanakan pada tanggal 06 Juli sampai dengan 24 Agustus 2019.

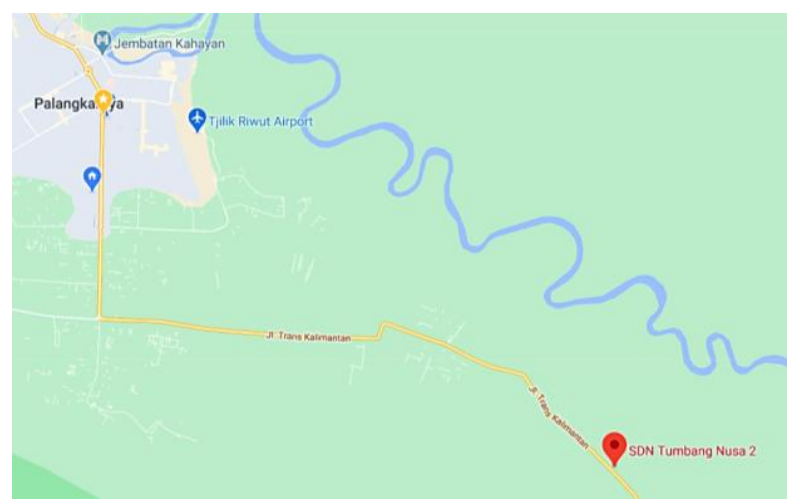

Gambar 1. Peta lokasi SDN Tumbang Nusa 2 Jabiren Pulang Pisau

Tim Pelaksana Kegiatan Pengabdian Masyarakat di SDN Tumbang Nusa 2 desa Taruna Jaya berjumlah 4 (empat) orang, terdiri dari 2 orang Dosen dan 2 orang Mahasiswa Prodi Kehutanan Fakultas Pertanian dan Kehutanan Universitas Muhammadiyah Palangkaraya. Target yang ingin dicapai dalam pengetahuan pendidikan lingkungan dan konservasi adalah sebagai berikut:

1. Meningkatkan pengetahuan anak-anak usia sekolah dalam memahami pentingnya lingkungan hidup bagi kehidupan sehari-hari mereka dan apa saja upaya konservasi yang bisa dilakukan secara sederhana.

2. Mampu mengaplikasikan teknik menanam pohon dengan baik.

3. Memberi keterampilan kepada anak-anak usia sekolah di dalam pemanfaatan barang bekas sehingga bernilai ekonomis.

\section{HASIL DAN PEMBAHASAN}

Kegiatan penyuluhan pendidikan lingkungan dilakukan melalui tahapan sebagai berikut:
1. Persiapan kegiatan meliputi:

a. Kegiatan survey tempat pengabdian masyarakat yaitu di SDN Tumbang Nusa 2 yang terletak di Desa Taruna Jaya Kecamatan Jabiren Raya Kabupaten Pulang Pisau Provinsi Kalimantan Tengah

b. Permohonan ijin kegiatan pengabdian masyarakat kepada pengurus dan Kepala Sekolah diSDNTumbang Nusa 2 yang terletak di Desa Taruna Jaya Kecamatan Jabiren Raya Kabupaten Pulang Pisau Provinsi Kalimantan Tengah

c. Pengurusan administrasi (surat-menyurat)

d. Persiapan alat dan bahan serta akomodasi

e. Persiapan tempat untuk pendidikan lingkungan (penyuluhan) yaitu menggunakan salah satu ruangan kelas di sekolah tersebut.

2. Kegiatan Pendidikan Lingkungan

a. Kegiatan pendidikan lingkungan (penyuluhan)

1) Pembukaan dan perkenalan dengan siswa/siswi di SDN Tumbang Nusa 2 yang terletak di Desa Taruna Jaya Kecamatan Jabiren Raya Kabupaten Pulang Pisau Provinsi Kalimantan Tengah yang menjadi sasaran kegiatan

2) pemutaran film mengenai “The Turtle Word" dan "Hutanku Meratap" serta diskusi mengenai hutan, manfaat hutan serta kebakaran serta dampaknya bagi lingkungan dan kesehatan.

3) Penyuluhan mengenai pengertian sampah, karakteristik sampah di sekolah, pengelolaan sampah, perencanaan pengelolaan sampah yang baik dan benar di sekolah

4) Praktek menggunakan masker yang benar.

5) Sesi diskusi/Tanya jawab dengan peserta penyuluhan kesehatan mengenai manajemen 
pembuangan sampah yang baik.

6) Pemberian door prize bagi peserta yang mampu menjawab pertanyaan

b. Kegiatan Penanaman Pohon

1) Praktek menanam pohon di halaman sekolah. Kegiatan praktek penanaman pohon dilaksanakan dihalaman sekolah, yaitu didepan kelas masing-masing kelas 1 sampai dengan kelas 6 dan diikuti oleh siswa kelas 1 sampai dengan kelas 6. Jenis tanaman yang ditanam adalah ketapang kencana dan ketapang daun lebar, jenis tanaman ini adalah tanaman yang mudah tumbuh dan tidak membutuhkan perawatan khusus, bagus sebagai tanaman peneduh karena tajuk lebar, memiliki fungsi sebagai tanaman penyerap karbon (udara kotor), menghasilkan oksigen untuk kepentingan mahluk hidup disekitar lingkungan sekolah.

2) Memberikan tanaman hias untuk di dalam ruang kelas, dari kelas 1 sampai dengan kelas 6 yaitu berupa tanaman bunga dari jenis krisan, kaktus kering dan amarilis, diharapkan dapat mempercantik ruang kelas dengan tanaman yang ada dan menumbuhkan rasa tenang karena kecantikan bunganya.

c. Kegiatan Keterampilan Kreativitas Anak, membuat sepeda dari kardus bekas

1) Membuat bunga dan daun dari kantong kresek

a) Kantung kresek bekas yang warna warni dipotong potong sesuai dengan ukuran kemudian dilipat seperti membuat kipas dari kertas (di selang seling kedepan dan kebelakang)

b) Ukur bagian tengah guntingan plastik tersebut ikat dengan kawat dan bunga tinggal dirapikan dengan membuka setiap helai lipatan kantong kresek tadi.

c) Kantung kresek digunting membentuk kerucut seperti daun (ada beberapa lapis supaya tebal) lalu lipat bagian tengah membentuk vertical dekatkan lilin untuk dipanaskan, akan menjadi bagian tulangan untuk daun yang dibentuk.

d) Tinggal merangkai bunga ataupun daun ke kawat yang menjadi tangkai bunga

2) Membuat pot bunga dari botol plastik

a) Botol Plastik bekas dipotong menjadi 2 bagian kemudian ambil bagian yang agak panjang dibagian ujung tempelkan ke bagian yang agak pendek,

b) Mulut botol yang pendek ditempelkan ke bagian botol yang panjang,

c) Dilem dengan lem lilin kemudian diberi hiasan.

3) Membuat sepeda

a) Ambil kardus lalu dibuat 3 buah lingkaran, beri lubang bagian tengahnya masing2 lingkaran dengan bantuan bekas tusuk sate untuk menghubungkan masing2 ban, tusuk sate digunakan sebagai stang sepeda dan badan sepeda.

b) Tutup botol diletakkan diantara kedua ban.

3. Penutupan

a. Foto bersama dengan peserta penyuluhan (siswa/siswi)

b. Berpamitan dengan pengurus dan Kepala Sekolah SDN Tumbang Nusa 2

Kegiatan pengabdian masyarakat pada SDN Tumbang Nusa 2 di Desa Taruna Jaya berjalan lancar dan diikuti oleh peserta didik yaitu siswa dari kelas 1 sampai dengan 
kelas 6 beserta para guru dengan sangat antusias, ini terbukti dari beberapa kali kunjungan tim pengabdian ke SDN Tumbang Nusa 2 disambut dengan ramah dan penuh kehangatan. Hasil yang dicapai pada kegiatan pengabdian ini yaitu berupa:

1. Tersosialisasikan materi mengenai konservasi hutan dan lingkungan kepada anak-anak sekolah usia dini sehingga anak-anak menjadi paham di dalam mengelola lingkungan hidup dan menambah khasanah pengetahuan mereka.

2. Adanya produk olahan dari barang bekas yaitu:
a. Plastik (kantong kresek) bekas menjadi bunga
b. Botol plastik minuman bekas menjadi pot bunga
c. Kardus bekas menjadi sepeda

3. Terbangunnya silaturahmi dengan pihak sekolah baik guru dan Murid di SDN. Tumbang Nusa 2, sekaligus juga mempromosikan Universitas Muhammadiyah melalui kegiatan ini.

4. Video Kegiatan di alamat, https://www.youtube.com/watch?v=PuTFL9teF6 g

\section{KESIMPULAN}

Melalui kegiatan pengabdian masyarakat kali ini, dalam hal ini mitra kami adalah anak-anak sekolah akan memiliki pemahaman mengenai pendidikan lingkungan dan konservasi, dimulai dari pengertian lingkungan, penyebab kerusakan lingkungan, cara mengelola lingkungan hidup disekitar sekolah, serta cara mengantisipasi kerusakan lingkungan. Selain itu, mitra juga diberikan pengetahuan mengenai cara menanam dan merawat pohon dengan benar di lingkungan sekolah serta mitra juga diberikan keterampilan membuat prakarya dari barang-barang bekas, seperti membuat bunga dan daun dari kantong kresek plastik, membuat pot bunga dari botol plastik minuman bekas dan membuat sepeda dari kardus bekas. Mitra diharapkan mampu mengaplikasikan pengetahuan yang mereka dapat dari penyuluhan dan pelatihan yang diberikan di dalam lingkungan sekolah maupun di luar lingkungan sekolah yang secara tidak langsung berfungsi untuk memberikan kepekaan bagi anak-anak sekolah terhadap lingkungan sekitarnya. Memberikan pelatihan lingkungan kepada masyarakat usia sekolah akan menghasilkan masyarakat yang sadar akan betapa pentingnya keadaan lingkungan yang seimbang untuk kehidupan yang sempurna. Namun pendidikan lingkungan tidak dapat dilakukan dalam waktu yang singkat, melainkan membutuhkan proses untuk menciptakan sumber daya manusia yang peduli akan lingkungan.

\section{UCAPAN TERIMA KASIH}

Kegiatan pengabdian masyarakat di lingkungan SDN Tumbang Nusa 2 sepenuhnya bersumber dari APBU Universitas Muhammadiyah Palangkaraya Tahun Anggaran 2019 melalui Lembaga Penelitian dan Pengabdian Kepada Masyarakat (LP2M) sesuai dengan Surat Perjanjian Penugasan Pelaksanaan Pengabdian Kepada Masyarakat Nomor 020.i/PTM.63.R10/LP2M/P/2018 Tanggal 23 Mei 2019.

\section{REFERENSI}

Budiwan, J. 2018. Pendidikan Orang Dewasa (Andragogy). Qalamuna: Jurnal Pendidikan, Sosial, dan Agama. 10(2):107-135. https://doi.org/10.5281/zenodo.3559265

Dahnial, I. 2020. Penerapan Model Pembelajaran Picture And Picture Terhadap Pendidikan Lingkungan Hidup (PLH) Untuk Meningkatkan Komptensi Guru Di SD Negeri Sekecamatan Stabat. JBS (Jurnal Berbasis Sosial). 1(1):81-90.

Effendi, R., Salsabila, H., Malik, A. 2018. Pemahaman Tentang Lingkungan Berkelanjutan. Modul. 18(2):75-82. 
https://doi.org/10.14710/mdl.18.2.2018.75-

82

Raunsay, E.K., Koireowa, D.C. 2019. Pendidikan Lingkungan Hidup (PLH) Sebagai Upaya Konservasi Cenderawasih Kuning Kecil Dengan Partisipasi Generasi Muda Di Kampung Barawai Distrik Raimbawi Kabupaten Kepulauan Yapen. Jurnal Pengabdian Papua. 3(2):55-60. https://doi.org/10.31957/.v3i2.938

Rivai, R.S., Anugrah, I.S. 2011. Konsep dan implementasi pembangunan Pertanian Berkelanjutan di Indonesia. Forum Penelitian Agro Ekonomi. 29(1):13-25.

http://dx.doi.org/10.21082/fae.v29n1.2011.1 3-25

Rusdiyanto. 2015. Masalah Lingkungan Hidup Indonesia Menghadapi Era Globalisasi. Jurnal Cakrawala Hukum. 6(2):215-227.

Sari, W.W. 2014. Persepsi Guru dan Siswa SD di Yogyakarta terhadap Program Conservation Scout. Jurnal Bioedukatika. 2(2):34-37. http://dx.doi.org/10.26555/bioedukatika.v2i 2.4126

Singkawijaya, E.B., Rosali, E.S., As'ari, R., Wulansari, W. 2019. Program Ecovillage Sebagai Sumber Belajar Untuk Meningkatkan Ecoliteracy Siswa. Jurnal Metaedukasi: Jurnal Ilmiah Pendidikan.1(1):25-31.

Subekti, S., Prayoga, I., Sudrajat, A.S.E. 2020. Pemberdayaan Masyarakat Dalam Pengelolaan Sampah Sebagai Upaya Penanganan Kawasan Kumuh Di Kawasan Pecangaan Kabupaten Jepara. Indonesian Journal of Spatial Planning. 1(2):45-50. http://dx.doi.org/10.26623/ijsp.v1i2.3105

Suradiakarta, D.A. 2008. Pemanfaatan Dan Strategi Pengembangan Lahan Gambut Eks PLG Kalimantan Tengah. Jurnal Sumberdaya Lahan. 2(1):31-44.

http://dx.doi.org/10.21082/jsdl.v2n1.2008.\% $25 \mathrm{p}$ 